\title{
Tingkat produktivitas karyawan dilihat dari perspektif lingkungan kerja sosial dan kepuasan kerja
}

\author{
L. A. Nazdia ${ }^{1}$, S. Sumiyati \& B. Widjajanta \\ Universitas Pendidikan Indonesia \\ lusianaarsyah@student.upi.edu
}

\begin{abstract}
The purpose of the research is to find out the influence of social work environment on productivity, the influence of job satisfaction on productivity, and the influence of social work environment and job satisfaction on productivity. The object used as analysis unit on this research is employees of electricity entreprise. The type of study is using verificative with the method is using an explanatory survey of 87 respondents. It was found that the influence of the social work environment to productivity are included in the category are very strong. Job satisfaction is very strong against the influential employee productivity. Social work environment and job satisfaction influence on productivity is very strong. The results also show that social work environment conducive conditions will increase employee productivity. The level of job satisfaction is high, then an electric company employee productivity will increase. In addition, if environmental conditions are conducive to social work and job satisfaction is high, then the employee productivity will increase.
\end{abstract}

Keyword: job satisfaction; productivity; social work environtment.

Abstrak: Tujuan penelitian yaitu untuk mengetahui pengaruh lingkungan kerja sosial terhadap produktivitas, pengaruh kepuasan kerja terhadap produktivita dan pengaruh lingkungan kerja sosial dan kepuasan kerja terhadap produktivitas. Objek yang menjadi unit analisis dalam penelitian ini adalah karyawan perusahaan listrik. Jenis penelitian yang digunakan adalah verifikatif dengan metode yang digunakan adalah explanatory survey dengan jumlah sampel 87 responden. Hasil penelitian ini menemukan bahwa pengaruh lingkungan kerja sosial terhadap produktivitas termasuk dalam kategori sangat kuat. Kepuasan kerja berpengaruh sangat kuat terhadap produktivitas karyawan. Lingkungan kerja sosial dan kepuasan kerja berpengaruh terhadap produktivitas sangat kuat. Dalam penelitian ini ditemukan jika kondisi lingkungan kerja sosial kondusif, maka akan meningkatkan produktivitas karyawan. Tingkat kepuasan kerja tinggi, maka produktivitas karyawan perusahaan listrik akan meningkat. Selain itu jika kondisi lingkungan kerja sosial kondusif dan kepuasan kerja tinggi, maka produktivitas karyawan akan meningkat.

Kata Kunci: kepuasan kerja; lingkungan kerja sosial, produktivitas.

\section{PENDAHULUAN}

Manusia sebagai sumber daya organisasi memiliki berbagai macam kebutuhan yang apabila terpenuhi memberikan motivasi dan produktivitas pada karyawan (Saeed, Waseem, Sikander, \& Rizwan, 2014). Produktivitas kerja karyawan sangat berpengaruh terhadap pencapaian target perusahaan sehingga rendahnya produktivitas kerja mengakibatkan perusahaan kesulitan mencapai tujuan yang telah ditentukan. Perusahaan dapat maju dan berkembang karena sumber daya manusia yang ada di dalamnya karena sumber daya manusia merupakan penggerak dari kemajuan suatu perusahaan (Sebastian Adiwijaya \& Senen, 2016). Suatu perusahaan juga perlu mengetahui pada tingkat produktivitas mana perusahaan tersebut beroperasi, agar dapat membandingkannya dengan produktivitas yang telah ditetapkan oleh manajemen (Masharyono, 2016b). 
Permasalahan produktivitas karyawan terjadi pada berbagai bidang industri seperti perbankan (Agbozo, Owusu, Hoedoafia, \& Atakorah, 2017), instansi pemerintahan (Bayarçelik \& Findikli, 2016), industry garment (Gyan, 2017), perhotelan (Marsden \& Moriconi, 2011), bidang kesehatan (Mailool, Pondaag, \& Lolong, 2017), serta industri jasa di bidang kelistrikan sebagai perusahaan penyedia listrik negara di Indonesia (Saputra, 2017). Berikut Tabel 1 yang menunjukkan indikator produktivitas kerja karyawan pada key performance indicator tahun 2015-2017.

Tabel 1. Key Performance Indicator Tahun 20152017

\begin{tabular}{llllc}
\hline Indikator & 2015 & 2016 & 2017 \\
\hline $\begin{array}{l}\text { Employee } \\
\text { Productivity }\end{array}$ & $\begin{array}{c}\text { MWhygdijual } \\
\text { pegawai teknis }\end{array}$ 100\% & $31.12 \%$ & $30.38 \%$ & $\begin{array}{c}28.41 \\
\%\end{array}$ \\
\hline
\end{tabular}

Sumber: Data Internal Perusahaan 2017

Dari Tabel 1 diatas menunjukkan indikator tingkat produktivitas karyawan dalam menghasilkan produk jasa. Hal ini menunjukkan bahwa karyawan belum mampu melakukan peningkatan produksi setiap tahunnya. Peningkatan produktivitas karyawan harus segera dilakukan seiring dengan bertambahnya pelanggan. Berikut Tabel 2 yang menunjukan pertumbuhan pelanggan di tahun 2012-2017.

Tabel 2. Data Pertumbuhan PelangganTahun 20122017

\begin{tabular}{lllll}
\hline Tahun & 2014 & 2015 & 2016 & 2017 \\
\hline $\begin{array}{l}\text { Jumlah } \\
\text { Pelanggan }\end{array}$ & 454.875 & 518.130 & 750.365 & 932.489 \\
\hline
\end{tabular}

Sumber: Data Internal Perusahaan 2017

Tabel 2 menunjukkan bahwa setiap tahunnya pelanggan meningkat yang menandakan harus adanya peningkatan pada kinerja karyawan. Perusahaan harus dapat memberikan kepuasan kepada masyarakat selaku pelanggan dan memberikan citra yang baik di mata masyarakat dengan cara memberikan pelayanan yang berkualitas. Jika pelayanan yang diberikan memenuhi permintaan pelanggan, maka pelanggan akan merasa puas dan bila jasa pelayanan berada di bawah tingkat yang diharapkan, pelanggan akan merasa tidak puas maka pengukuran kepuasan akan pelayanan yang diberikan oleh perusahaan harus selalu dilakukan untuk mengetahui dan merencanakan strategi yang lebih baik di masa mendatang dan berupaya meningkatkan produktivitas pelayanannya dalam penyediaan listrik karena banyaknya keluhan dari pelanggan mengenai pelayanan listrik.

Teori yang digunakan untuk mengatasi permasalahan perusahaan yaitu pendekatan manajemen sumber daya manusia (Amstrong, 2017). Faktor-faktor yang mempengaruhi produktivitas yaitu knowledge, skill, ability, attitude, behaviou. Menurut penelitian terdahulu faktor-faktor yang mempengaruhi produktivitas karyawan yaitu 1) kepemimpinan, 2) kompensasi, 3) pengawasan kerja, 4) lingkungan kerja, 5) pendidikan dan pelatihan, 6) disiplin kerja, 7) fasilitas kerja. 8) absensi kerja, 9) beban kerja, 10) tingkat perputaran karyawan, dan 11) proses seleksi menurut Nitisemito (2001). Faktor lainnya yang menjadi penyebab tingkat produktivitas adalah stres kerja (Dhania, 2010), komunikasi (Ernst Kossek et al., 2012), kemampuan serta keselamatan kesehatan dan karyawan (Karatepe, 2013).

Produktivitas disebabkan adanya penuruan kinerja karyawan akibat permasalah lingkungan, beban kerja, dan kepuasan (Musriha, 2011). Penelitian mengatakan bahwa kepuasan kerja berkaitan erat dengan pribadi karyawan sebagai cerminan perasaan seseorang terhadap pekerjaannya (Halkos, Bousinakis, Halkos, \& Bousinakis, 2015). Sejalan dengan penelitian yang dilakukan oleh (Nikolaos, 2015) Peningkatan produktivitas kerja karyawan dapat dilakukan dengan berbagai cara, salah satunya memperbaiki lingkungan kerja menjadi lebih kondusif dan nyaman.

Berdasarkan latar belakang masalah diatas, maka penulis merumuskan beberapa rumusan penelitian yaitu bagaimana pengaruh lingkungan kerja sosial terhadap produktivitas karyawan di perusahaan listrik, bagaimana pengaruh kepuasan kerja terhadap produktivitas karyawan di perusahaan listrik, dan pengaruh lingkungan kerja sosial dan kepuasan kerja terhadap produktivitas karyawan perusahaan listrik. Tujuan dari penelitian ini adalah untuk mengetahui pengaruh lingkungan kerja sosial terhadap produktivitas karyawan 
karyawan di perusahaan listrik, pengaruh kepuasan kerja terhadap produktivitas karyawan di perusahaan listrik, dan pengaruh lingkungan kerja sosial dan kepuasan kerja terhadap produktivitas karyawan di perusahaan listrik.

\section{METODE PENELITIAN}

Metode yang digunakan dalam penelitian ini adalah metode survey atau explanatory survey. Metode ini bertujuan untuk mengetahui pengaruh antar variabel dengan cara pengujian hipotesis. Data yang digunakan adalah data sekunder yang terdiri dari data key performance indicator, data pertumbuhan pelanggan, data rekapitulasi keluhan perjenis keluhan, data response time, pra penelitian.

Sampel dalam penelitian ini adalah seluruh karyawan perusahaan listrik, penarikan sampel dengan menggunakan metode sampel jenuh, yaitu metode yang mengambil seluruh jumlah populasi. Teknik pengumpulan data yang dilakukan dalam penelitian ini melalui penyebaran kuesioner dan wawancara. Teknik analisis data yang digunakan dalam penelitian ini adalah analisis verifikatif. Analisis verifikatif digunakan untuk untuk melihat pengaruh lingkungan kerja sosial dan kepuasan kerja terhadap produktivitas (Sugiyono, 2017: 147).

Variabel dalam penelitian terdiri dari lingkungan kerja sosial, kepuasan kerja dan produktivitas. Penelitian ini menggunakan pengukuran data berskala interval. Skala berusaha mengukur arti suatu objek atau konsep bagi responden. Skala yang digunakan dalam penelitian ini adalah skala Semantic Differential.

\section{HASIL DAN PEMBAHASAN}

Penelitian ini yang terdiri dari variabel bebas yaitu lingkungan kerja sosial $\left(\mathrm{X}_{1}\right)$ dan kepuasan kerja $\left(\mathrm{X}_{2}\right)$, sedangkan untuk variabel terikatnya adalah produktivitas (Y). Untuk mengetahui pengaruh lingkungan kerja sosial terhadap produktivitas, pengaruh kepuasan kerja terhadap produktivitas, dan pengaruh lingkungan kerja sosial dan kepuasan kerja terhadap produtivitas dilakukan pengujian regresi linier berganda.
Model persamaan regresi berganda yang akan dibentuk pada penelitian ini sebagai berikut..

$$
\mathbf{Y}=\mathbf{a}+\mathbf{b}_{1} \mathbf{X}_{1}+\mathbf{b}_{2} \mathbf{X}_{2}+\mathbf{e}
$$

Sumber: Sugiyono $(2017 ; 192)$

Dimana :

$\mathrm{Y} \quad=$ Produktivitas

$\mathrm{X}_{1} \quad=$ Lingkungan kerja sosial

$\mathrm{X}_{2} \quad=$ Kepuasan kerja

$\mathrm{a}=$ Bilangan konstanta

$\mathrm{b}_{1,2} \quad=$ Koefisien regresi

$\mathrm{e} \quad=$ Kesalahan pengganggu (standart error)

Berdasarkan hasil pengolahan data dengan bantuan program SPSS 24.0 for windows, diperoleh koefisien regresi linear berganda sebagai berikut.

Tabel 3. Koefisien korelasi model summary

\begin{tabular}{|c|c|c|c|c|c|}
\hline \multicolumn{6}{|l|}{ Coefficients $^{\mathrm{a}}$} \\
\hline & \multicolumn{5}{|c|}{ Unstandardized Standardized } \\
\hline & \multicolumn{2}{|c|}{ Coefficients } & \multirow[t]{2}{*}{ Coefficients } & \multirow{3}{*}{\multicolumn{2}{|c|}{$\mathrm{Sig}$}} \\
\hline & & Std. & & & \\
\hline Model & $\mathrm{B}$ & Error & Beta & $\mathrm{t}$ & \\
\hline 1 (Constant) & .657 & 1.099 & & .598 & .551 \\
\hline $\begin{array}{l}\text { Lingkungan } \\
\text { Kerja }\end{array}$ & .252 & .071 & .325 & 3.53 & 4.001 \\
\hline Kompensasi & 1.304 & .044 & 632 & 6.86 & 9.000 \\
\hline
\end{tabular}

a. Dependent Variable: Produktivitas

Sumber: Hasil Pengolahan Data, 2018

Berasarkan Tabel 3 pada kolom B, tercantum nilai konstanta dan nilai koefisien regresi linear sederhana untuk variabel bebas. Berdasarkan nilainilai itu maka dapat ditentukan model regresi linear sederhana yang dinyatakan dalam bentuk persamaan sebagai berikut:

$$
\begin{gathered}
\mathbf{Y}=\mathbf{a}+\mathbf{b}_{1} \mathbf{X}_{\mathbf{1}}+\mathbf{b}_{2} \mathbf{X}_{\mathbf{2}}+\mathbf{e} \\
\mathrm{Y}=0,657+0,252 \mathrm{X} 1+0,304 \mathrm{X} 2
\end{gathered}
$$

Berdasarkan persamaan regresi linier berganda di atas, menunjukkan bahwa koefisien regresi lingkungan kerja sosial $\left(b_{1}\right)$ bernilai positif. Hal ini menunjukkan adanya arah hubungan dari persamaan positif yang menggambarkan adanya hubungan positif, artinya lingkungan kerja sosial mempunyai hubungan searah dengan produktivitas. Dapat dikatakan jika lingkungan kerja sosial mengalami kenaikan, maka nilai produktivitas akan meningkat, begitu pun sebaliknya, jika lingkungan kerja sosial mengalami penurunan, maka nilai produktivitas akan menurun. 
Koefisien regresi pada variabel kepuasan kerja $\left(b_{2}\right)$ bernilai positif. Hal ini menunjukkan adanya hubungan dari persamaan positif yang menggambarkan adanya hubungan positif, artinya kepuasan kerja mempunyai hubungan searah dengan produktivitas. Dapat dikatakan jika kepuasan kerja mengalami kenaikan, maka nilai produktivitas akan meningkat, begitu pun sebaliknya, jika kepuasan kerja mengalami penurunan, maka nilai produktivitas akan menurun.

Untuk mengetahui besarnya persentase pengaruh $\mathrm{X}_{1}$ dan $\mathrm{X}_{2}$ terhadap $\mathrm{Y}$, koefisien determinasi dapat diketahui dengan rumus yang dikemukakan Riduwan (2013: 136) yaitu :

$$
\mathrm{KD}=\mathbf{r}^{2} \times 100 \%
$$

Keterangan :

$\mathrm{KD}=$ Koefisien determinasi

$\mathrm{r}=$ Koefisien korelasi

$100 \%=$ Konstanta

Pengaruh lingkungan kerja terhadap kepuasan kerja dapat dilihat dari hasil Tabel 4 berikut:

Tabel 4. Koefisien Determinasi Secara Parsial

\begin{tabular}{|c|c|c|}
\hline \multicolumn{3}{|c|}{ Model Summary ${ }^{\mathrm{b}}$} \\
\hline & Adjusted R & Std. Error of the \\
\hline ModelR & SquareSquare & Estimate \\
\hline $.900^{\mathrm{a}}$ & $\begin{array}{ll}.811 & .809\end{array}$ & 2.64716 \\
\hline
\end{tabular}

a. Predictors: (Constant), Lingkungan Kerja Sosial

b. Dependent Variable: Produktivitas

Sumber: Hasil Pengolahan Data, 2018

$\mathrm{KD}=\mathrm{r}^{2} \times 100 \%$

$=(0,900)^{2} \times 100 \%$

$=81,1 \%$

Angka koefisien korelasi (R) sebesar 0,900. Hal ini berarti bahwa hubungan antar lingkungan kerja sosial dengan produktivitas sebesar 0,900. Dari angka tersebut jika diinterpretasikan dapat diambil kesimpulan bahwa hubungan antara variabel lingkungan kerja sosial dengan variable produktivitas adalah sangat kuat.

Dari hasil penghitungan koefisien determinasi untuk lingkungan kerja sosial dengan produktivitas adalah $81,1 \%$. Dengan kata lain lingkungan kerja sosial mempengaruhi produktivitas sebesar $81,1 \%$ sedangkan $18,9 \%$ dipengaruhi oleh faktor-faktor lainnya diluar lingkungan kerja sosial.
Pengaruh kepuasan kerja terhadap produktivitas dapat dilihat dari hasil Tabel 5 berikut:

Tabel 5. Koefisien Determinasi Secara Parsial

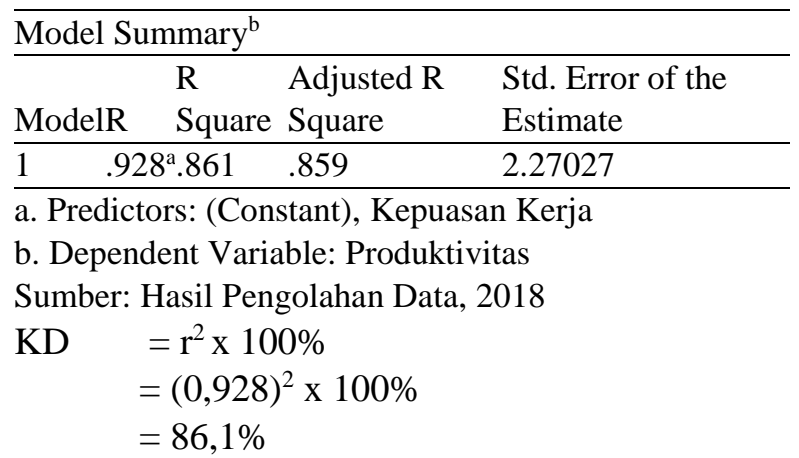

Angka koefisien korelasi (R) sebesar 0,928. Hal ini berarti bahwa hubungan antar kepuasan kerja dengan produktivitas sebesar 0,928. Dari angka tersebut jika diinterpretasikan dapat diambil kesimpulan bahwa hubungan antara variabel kepuasan kerja dengan variabel produktivitas adalah sangat kuat.

Dari hasil penghitungan koefisien determinasi untuk kepuasan kerja terhadap produktivitas adalah $86,1 \%$. Dengan kata lain kepuasan kerja mempengaruhi produktivitas sebesar $86,1 \%$ sedangkan $13,9 \%$ dipengaruhi oleh faktor-faktor lainnya diluar kepuasan kerja.

Adapun pengaruh lingkungan kerja sosial dan kepuasan kerja terhadap produktivitas dapat dilihat dari hasil Tabel 6 berikut:

Tabel 6. Koefisien Determinasi Secara Simultan

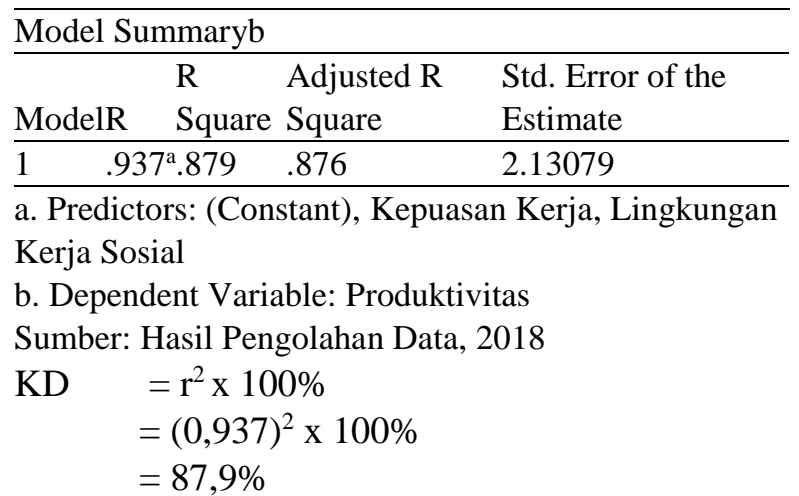

Angka koefisien korelasi (R) sebesar 0,937. Hal ini berarti bahwa hubungan antar lingkungan kerja sosial dan kepuasan kerja terhadap produktivitas sebesar 0,937. Dari angka tersebut jika diinterpretasikan dapat diambil kesimpulan 
bahwa hubungan antara variabel lingkungan kerja sosial dan kepuasan kerja terhadap produktivitas adalah sangat kuat.

Dari hasil penghitungan koefisien determinasi untuk lingkungan kerja sosial dan kepuasan kerja terhadap produktivitas adalah $87,9 \%$. Dengan kata lain produktivitas dipengaruhi lingkungan kerja sosial dan kepuasan kerja kerja sebesar 87,9\% sedangkan $12,1 \%$ dipengaruhi oleh faktor-faktor lainnya diluar lingkungan kerja sosial dan kepuasan kerja kerja.

Uji statistik $t$ pada dasarnya menunjukkan seberapa jauh pengaruh satu variabel penjelas/independen secara individual dalam menerangkan variabel dependen. Untuk mengetahui besarnya persentase pengaruh lingkungan kerja dan kompensasi terhadap kepuasan kerja. Maka menggunakan program SPSS 24.0 for windows, diperoleh output sebagai berikut:

Tabel 7. Nilai Signifikan Uji t

\begin{tabular}{|c|c|c|c|c|c|}
\hline \\
\hline \multicolumn{6}{|c|}{$\frac{\text { Coefficients }^{\mathrm{a}}}{\text { UnstandardizedStandardized }}$} \\
\hline \multirow[b]{2}{*}{ Model } & \multicolumn{2}{|c|}{ Coefficients } & \multicolumn{2}{|c|}{ Coefficients } & \multirow[b]{2}{*}{ Sig. } \\
\hline & B & $\begin{array}{l}\text { Std. } \\
\text { Error }\end{array}$ & Beta & $\mathrm{T}$ & \\
\hline 1 (Constant) & .657 & 1.099 & & .598 & .551 \\
\hline \multicolumn{6}{|l|}{ Lingkungan } \\
\hline Kerja & .252 & .071 & .325 & 3.534 & .001 \\
\hline \multicolumn{6}{|l|}{ Sosial } \\
\hline $\begin{array}{l}\text { Kepuasan } \\
\text { Kerja }\end{array}$ & .304 & .044 & .632 & 6.869 & .000 \\
\hline
\end{tabular}

a. Dependent Variable: Produktivitas

Sumber: Hasil Pengolahan Data, 2018

Berdasarkan Tabel 7 hasil uji-t pengaruh lingkungan kerja sosial terhadap produktivitas dengan SPSS diperoleh nilai $t_{\text {hitung }}=3,534$ dengan tingkat signifikansi 0,001 . Dengan menggunakan batas signifikansi 0.05 , nilai signifikansi tersebut berada di bawah 5\% dan $\mathrm{t}_{\text {hitung }}$ sebesar 3,534 $>\mathrm{t}_{\text {tabel }}$ sebesar $1.989(\mathrm{df}=87-3=84, \alpha=5 \%)$. Kenaikan 1 standardized lingkungan kerja sosial akan meningkatkan 0,325 nilai produktivitas, artinya semakin tinggi lingkungan kerja sosial maka semakin tinggi produktivitas. Dengan demikian $\mathrm{Ho}_{1}$ ditolak dan $\mathrm{Ha}_{1}$ diterima artinya koefisien beta (koefisien jalur) lingkungan kerja sosial sebesar 0,325, menunjukkan arah hubungan positif terhadap produktivitas pada karyawan perusahaan listrik.

Berdasarkan Tabel 7 hasil uji-t pengaruh kepuasan kerja terhadap produktivitas dengan SPSS diperoleh nilai thitung $=6,869$ dengan tingkat signifikansi 0,000. Dengan menggunakan batas signifikansi 0.05 , nilai signifikansi tersebut berada di bawah $5 \%$ dan $t_{\text {hitung }}$ sebesar $6,869>t_{\text {tabel }}$ sebesar 1.989 $(\mathrm{df}=87-3=84, \quad \alpha=5 \%) . \quad$ Kenaikan 1 standardized kepuasan kerja akan meningkatkan 0,632 nilai produktivitas, artinya semakin tinggi kepuasan kerja maka semakin tinggi produktivitas. Dengan demikian $\mathrm{Ho}_{2}$ ditolak dan $\mathrm{Ha}_{2}$ diterima artinya koefisien beta (koefisien jalur) kepuasan kerja sebesar 0,632 menunjukkan arah hubungan positif terhadap produktivitas pada karyawan perusahaan listrik.

Uji statistik F pada dasarnya menunjukkan apakah semua varibel independen atau bebas yang dimasukkan dalam model mempunyai pengaruh secara bersama-sama terhadap variabel dependen/terikat. Uji ini digunakan untuk menguji siginifikansi pengaruh lingkungan kerja sosial dan kepuasan kerja terhadap produktivitas rumus uji $\mathrm{F}$ atau uji ANOVA dijelaskan pada tabel berikut.

Tabel 8. Nilai Signifikan Uji F

\begin{tabular}{llllll}
\hline ANOVA $^{\mathrm{a}}$ & \multicolumn{4}{c}{} \\
\hline & $\begin{array}{l}\text { Sum of } \\
\text { Model }\end{array}$ & \multicolumn{2}{c}{ Mean } \\
Squares & df Square & F & Sig. \\
\hline 1 Regression2767.246 & 2 & 1383.623 & $304.746 .000^{\mathrm{b}}$ \\
Residual & 381.382 & 844.540 & & \\
Total & 3148.628 & 86 & & \\
\hline
\end{tabular}

a. Dependent Variable: Produktivitas

b. Predictors: (Constant), Kepuasan Kerja, Lingkungan Kerja Sosial

Sumber: Hasil Pengolahan Data, 2018

Berdasarkan Tabel 6 pengujian pengaruh variabel bebas secara bersama-sama terhadap variabel terikatnya dilakukan dengan menggunakan uji F. Hasil perhitungan statistik menunjukan nilai $F_{\text {hitung }}=304,746>F_{\text {tabel }}=3,104$ $\left(\mathrm{df}_{1}=3-1=2, \mathrm{df}_{2}=87-2=85, \alpha=5 \%\right)$ dan signifikansi sebesar $0,000<0,05$. Dengan demikian dapat disimpulkan bahwa hipotesis dalam penelitian ini 
yaitu $\mathrm{H}_{0}$ ditolak dan $\mathrm{H}_{\mathrm{a}}$ diterima, sehingga secara bersama-sama terdapat pengaruh antara lingkungan kerja sosial dan kepuasan kerja terhadap produktivitas di perusahaan listrik.

\section{KESIMPULAN DAN SARAN}

Hasil penelitian menyatakan bahwa, lingkungan kerja sosial mempunyai pengaruh terhadap produktivitas karyawan dengan kategori sangat kuat. Hal ini menunjukkan bahwa semakin kondusif lingkungan kerja sosial perusahaan, maka semakin tinggi pula produktivitas karyawan perusahaan listrik. Kepuasan kerja berpengaruh terhadap produktivitas karyawan dengan kategori sangat kuat, hal tersebut menunjukkan bahwa semakin tinggi kepuasan kerja di perusahaan, maka akan semakin tinggi pula produktivitas karyawan di perusahan listrik. Hasil lainnya adalah lingkungan kerja sosial dan kepuasan kerja berpengaruh terhadap produktivitas karyawan dengan kategori sangat kuat. Hal tersebut menjelaskan bahwa semakin kondusif lingkungan kerja sosial dan semakin tinggi kepuasan kerja karyawan, maka akan semakin tinggi produktivitas karyawan perusahaan listrik.

Berdasarkan hasil penelitian, maka penulis menyarankan beberapa hal yang dapat meningkatkan produktivitas karyawan melalui lingkungan kerja sosial. Perusahaan harus memberikan dorongan agar dapat menjaga hubungan baik dengan bawahan. Sedangkan untuk meningkatkan produktivitas karyawan melalui kepuasan kerja dapat dilakukan dengan cara perusahaan memberikan promosi yang sesuai untuk karyawan demi kemajuan organisasi.

\section{DAFTAR PUSTAKA}

Agbozo, G. K., Owusu, I. S., Hoedoafia, M. A., \& Atakorah, Y. B. (2017). The Effect Of Work Environment On Job Satisfaction: Evidence From The Banking Sector In Ghana. Journal Of Human Resource Management, 5(1), 12-18. Https://Doi.Org/10.11648/J.Jhrm.20170501.12

Armstrong, M. \& S. T. (2017). Handbook Of Human Resource Management (13th Ed.). Uk: Ashford Colour Press Ltd.

Bayarçelik, E. B., \& Findikli, M. A. (2016). The Mediating Effect Of Job Satisfaction On The
Relation Between Organizational Justice Perception And Intention To Leave. Procedia Social And Behavioral Sciences, 235(October), 403-411. Https://Doi.Org/10.1016/J.Sbspro.2016.11.050

Dhania, D. R. (2010). Pengaruh Stres Kerja , Beban Kerja Terhadap Kepuasan Kerja ( Studi Pada Medical Representatif Di Kota Kudus ). Psikologi Universitas Muria Kudus, I(1), 15-23.

Ernst Kossek, E., Kalliath, T., \& Kalliath, P. (2012). Achieving Employee Wellbeing In A Changing Work Environment. International Journal of Manpower, 33(7), 738-753. Https://Doi.Org/10.1108/01437721211268294

Ghozali, I. (2016). Aplikasi Analisis Multivariate Dengan Program Ibm Spss 23. Semarang: Badan Penerbit Universitas Diponegoro.

Gyan, A. K. (2017). Moderating Role Of Productivity On Diversified Conglomerates And Performance: The Case Of Malaysia. Asia-Pacific Journal Of Business Administration, 9(2), 118-133. Https://Doi.Org/10.1108/Apjba-08-2016-0084

Halkos, G., Bousinakis, D., Halkos, G., \& Bousinakis, D. (2015). The Effect Of Stress And Satisfaction On Productivity. Https://Doi.Org/10.1108/17410401011052869

Karatepe, O. M. (2013). International Journal Of Hospitality Management High-Performance Work Practices And Hotel Employee Performance: The Mediation Of Work Engagement. International Journal Of Hospitality Management, 32, 132-140. Https://Doi.Org/10.1016/J.Ijhm.2012.05.003

Luthans, Fred. (2014). Organization Behavior. New York: McGraw Hill International.

Mailool, C. M., Pondaag, L., \& Lolong, J. (2017). Hubungan Faktor Personal Dengan Kinerja Perawat Pelaksana Di Instalasi Rawat Inap Rsu Pancaran Kasih Gmim Manado. Ejournal Keperawatan, 5(1).

Marsden, D., \& Moriconi, S. (2011). The Impact Of Employee Well-Being Policies And Sickness Absence On Workplace Performance. Advances In Industrial And Labor Relations (Vol. 18). Emerald. Https://Doi.Org/10.1108/S07426186(2011)0000018007

Masharyono. (2016b). Pengaruh Kualitas Produk Terhadap Kepuasan Konsumen Pada Celdi Katering ( Survei Pada Konsumen Celdi Katering ) Effect Of Product Quality On Customer Satisfaction In Catering Celdi ( Survey On Consumer Celdi Catering ), 152-166.

Musriha. (2011). Influences Of Work Behavior, Work Environment And Motivation In Clove Cigarette Factories In Kudus , 1(3), 303-314.

Nitisemito, A. S. (2001). Manajemen Personalia. Jakarta: Ghalia Indonesia. 
Nikolaos, A. (2015). The Workplace As A Factor Of Job Satisfaction And Productivity. Https://Doi.Org/10.1108/Jfm-06-2014-0018

Priyono. (2016). Metode Penelitian Kuantitatif. (T. Chandra, Ed.) (Edisi Revi). Sidoarjo: Zifatama Publishing.

Robbins, P. S. Dan, \& Coulte, M. (2012). Management. (P. H. L. S. One, Ed.). Pearson Education In.

Saeed, I., Waseem, M., Sikander, S., \& Rizwan, M. (2014). The Relationship Of Turnover Intention With Job Satisfaction, Job Performance, Leader Member Exchange, Emotional Intelligence And Organizational Commitment. International Journal Of Learning \& Development, 4(2), 242-256. Https://Doi.Org/10.5296

Saputra, A. A. (2017). Pengaruh Program Kesehatan Dan Keselamatan Kerja K3 Terhadap Produktivitas Kerja Pada Pt. Pln (Persero) Cabang Pinrang.

Sedarmayanti. (2011). Tata Kerja dan Produktivitas Kerja: Suatu Tinjauan Dari Aspek Ergonomi Atau Kaitan Antara Manusia Dengan Lingkungan Kerjanya (Ketiga). Bandung: Mandar Maju.

Sugiyono. (2017). Metode Penelitian Kuantitatif, Kualitatif dan $R \& D$. Bandung: Alfabeta. 